\title{
The politics of community: Togetherness, transition and post-politics
}

Environment and Planning $\mathrm{A}$

0 (0) $1-19$

(C) The Author(s) 2017 Reprints and permissions: sagepub.co.uk/journalsPermissions.nav DOI: $10.1177 / 03085$ |8X17724443 journals.sagepub.com/home/epn

@SAGE

\section{Gerald Taylor Aiken}

Université du Luxembourg, Luxembourg

\begin{abstract}
This article excavates the role, function and practices of community within Transition, a grassroots environmentalist movement. It does so to pursue a quest for understanding if, how, and in what ways, community-based environmental movements are 'political'. When community-based low carbon initiatives are discussed academically, they can be critiqued; this critique is in turn often based on the perception that the crucial community aspect tends to be a settled, static and reified condition of (human) togetherness. However community-both in theory and practice - is not destined to be so. This article collects and evaluates data from two large research projects on the Transition movement. It takes this ethnographic evidence together with lessons from post-political theory, to outline the capacious, diverse and progressive forms of community that exists within the movement. Doing so, it argues against a blanket postpolitical diagnosis of community transitions, and opens up, yet again, the consequences of the perceptions and prejudices one has about community are more than mere theoretical posturing.
\end{abstract}

\section{Keywords}

Low carbon transitions, community, environmentalism, post-politics

\section{Introduction}

This paper analyses the community rhetoric and practice of current grassroots environmental movements, taking its argument from the most prominent group using community: Transition. Founded in 2006, this permaculture-inspired community movement has 'undergone rapid development to become a global brand' (Grossmann and Creamer, 2016: 1). Their headline concerns are climate change and peak oil, but Transition talk as much about localisation, relocalisation, resilience and local economy (Hopkins, 2011, 2008a). Transition's do-it-yourself environmentalism sits against the backdrop of increasing environmental concerns, but also growing grassroots popularity and government promotion of community action (Agyeman et al., 2016; Barr and Devine-Wright, 2012; Bulkeley and Fuller, 2012; Creamer, 2015; Hauxwell-Baldwin, 2013; Hobson et al., 2016a; Taylor Aiken, 2016).

\section{Corresponding author:}

Gerald Taylor Aiken, Universite du Luxembourg, Faculte des Lettres, des Sciences humaines, des Arts et des Sciences de I'Education II, Porte des Sciences, Belval, Esch-sur-Alzette L-4366, Luxembourg.

Email: gerald.aiken@uni.lu 
Re-localisation, eco-localisation and community-led transition movements abound both on the ground and increasingly in academic analysis (Feola and Nunes, 2014; Merritt and Stubbs, 2012; Middlemiss, 2011a, 2011b; Moloney et al., 2010; North, 2011, 2010; North and Longhurst, 2013; Taylor Aiken et al., 2017; Walker, 2011). 'Relocalisation' (Bailey et al., 2010) is an 'emergence of a new form of environmental activism, which is neither characterised by the politics of protest nor by the passivity of the Neo-liberal citizenconsumer' (Barr and Pollard, 2016: 2). This broader movement is both represented by Transition - relocalisation's brightest star-but many relocalisation initiatives find visibility and a niche within Transition's capacious umbrella too (Hopkins, 2011, 2008a). Transition are the most prominent, certainly in the UK, example of what Hobson et al. (2016a) call low carbon community groups and partnerships (LCCGPs). They form over 500 groups in the UK and Feola and Him (2016: 1) report over 1100 Transition initiatives worldwide. Transition emphasise the 'considerable diversity' (Hobson et al., 2016a: 2) of such initiatives, despite commonalities that can be found in the types of people, places and activities involved. For Grossmann and Creamer (2016) Transition's diversity is spatially uneven; some initiatives more diverse than others, and also more wished for than realised-diversity found more in Transition's philosophy than their practice. This is important in two regards; first, the evidence presented here will necessarily be partial, reflecting specific cases, rather than the entire field of either literature on such groups or the complete movement. Second, awareness of this unevenness provides an important note to be cautions of any theory either praising or dismissing a whole movement, on the basis of select evidence.

This paper seeks to re-examine fundamental tenants of what it means to be post-political, in the light of Transition, a case study that is regularly claimed to be just that. At the heart of the paper is an ontological claim, that while the political/post-political diagnosis can reveal aspects of both community and grassroots environmentalism, it often mistakenly accompanies presuppositions about community. It takes seriously and not without good reason the claims of the post-political critique. Yet the paper also seeks to see Transition in the light of literature and participants praising Transition. Crucially, it does this though the eyes of Transition itself. The paper thus seeks to see what Transition has to say to these theoretical frames, rather than adopting a frame and then looking for evidence within empirical examples.

Each Transition initiative has togetherness as 'community' as its raison d'être (Brangwyn, 2010: n.p.; Aiken, 2012). Acting as a community, in local communities, is necessary for building the resilient relocalised community Transition ultimately desires. As we shall see though, this community is integral not only to Transition's sympathisers but also their critics. This article emerges from an awareness that while many of those involved in such groups and movements can feel empowered, encouraged and increasingly capable of taking environmental actions, some, but not all, academic literature is critical, at times dismissive, of this. These critiques are often based on a post-political diagnosis, which in turn is based on an argument that 'community' is post-political (Neal, 2013). Thus, the article seeks to fold an investigation into the use (and abuse) of community within grassroots environmentalism and the ways in which Transition has often been academically received.

The paper is structured as follows. First, it considers the ways social scientists have charted community-based environmentalist activism, particularly parsing the reasons why these initiatives are viewed positively or critically. As criticisms are regularly based on a broad post-political diagnosis of Transition, in particular their vision and practice of community, the second section delves deeper into plotting Transition's community, in the light of key aspects of post-political theory. Then, third, the article outlines two research 
projects that studied four separate Transition initiatives, and the approaches taken here. From this research three generative themes emerge. The common aspects to each initiative are that Transition: use ecological metaphors, are practical, and heterogeneous. The article outlines these aspects of Transition, seeking to reevaluate each characteristic in the light of the post-political critique. Doing so the article attempts to provide a nuanced account of the politics of community, in the ways community is used to pursue environmental goals. Accordingly, the article concludes that while the post-political critique of Transition is not misplaced, it should not be overstated.

\section{Community transitions}

Transition initiatives are often viewed positively. Cretney et al. discuss the 'locally rooted but outward looking nature of Transition activities' (2016: 81). Transition are seen as 'progressive localism', exemplar of 'new environmentalism' (Staggenborg and Ogrodnik, 2015). Grassroots innovations literature points to the potential small, local and niche initiatives have to transform wider social and economic arrangements (Smith et al., 2016). Middlemiss and Parrish note 'the importance of community as a space for realising proenvironmental change' (2010: 755). Transition are claimed to 'exemplify the potential of social movements to create spaces of possibility for alternatives to mainstream, neoliberal economics' (Feola and Him, 2016: 1). They offer 'a radical alternative template of spatial relations to that of globalisation' (Bailey et al., 2010: 595). These 'microcosms of hope' (Bailey et al., 2010) form a 'progressive response to climate change and peak oil' (North, 2010).

So far, so good. Yet a separate strand of literature exits which is critical of the potential of grassroots community-action for sustainability (Chatterton and Cutler, 2008; Dilley, 2017; Kenis and Lievens, 2015: 18-39, 2014; Kenis and Mathijs, 2014a; Mason and Whitehead, 2012; Neal, 2013). Kenis and Mathijs (2014a) for instance outline how those who initiate, gel and drive forward community often dominate the following activities, which can have an exclusionary effect for those with alternative visions. Not only does this literature disagree that Transition's activities provide hope and potential for transforming economy and society. Critique along these lines posits that groups like Transition, alongside their insignificance, can actually hinder or prevent possible progress on the social, economic and environmental challenges they address. Here Transition performs a post-political function. They elide fundamental challenges, and provide a cozy feeling of activity, all the while leaving the causal mechanisms of their foci unaddressed. The focus on symptoms not causes - what Žižek (1999) calls 'pseudo-activity' - is a threat to progressive political action. Thus, the focus on well-meaning, but fluffy or empty rhetoric like community and sustainability can actually preclude significant action on social or environmental challenges.

Perhaps the most well known critique of Transition comes from the academic/activist collective Trapese. Here, Transition are inherently apolitical, due to their focus on smallscale, achievable, pragmatic and consensual local actions: 'transition is merely 'coping' or tinkering where more radical forms of change are required' (Brown et al., 2012: 1608). Transition rejects direct action and seeks to undermine rather than directly confront society's larger structures: the organisations and sedimented norms and power relations responsible for climate change (Chatterton and Cutler, 2008). Kenis and Mathijs (2014b: 153) echo Cook and Swyngedouw's comment that this action on climate is only to ensure 'that nothing really changes' (2012: 1973). Directly responding to Trapese's provocations, founder Hopkins (2008b) argued Transition was different to conventional, confrontational activism; potentially achieving more on environmental challenges by avoiding backing any 
particular political party. Both these views to a certain extent speak past each other. Avoiding party politics or formal democratic mechanisms does not make one apolitical or post-political. Nor does an active engagement and participation in formal political organisations and structures make one 'properly political', here taken to be 'practices that go beyond the status quo of intense individualism, corrosive consumerism and financial austerity' (Chatterton, 2016: 2). How then can we evaluate the political character of Transition?

North (2011: 1588) emphasises that Transition - amongst other low carbon community movements, such as CRAG's - are self-declared as apolitical. In making this argument, North's charge sheet is similar to others making this same claim: participants work to reduce their personal carbon footprint 'with moral support from the group'; often located in 'quite well-heeled rural small towns and composed of highly educated members'; but most importantly they 'favour working in a very consensual way', 'under the radar', 'not conceptualizing anyone as an "enemy", (North, 2011: 1588). North however digs deeper than this surface reading; not theoretically - many dismissals of Transition as post-political are based on Mouffe (2005), Rancière or Schmitt's friend/enemy distinction (Schmitt, 2005, 2007) - but empirically. North takes groups like Transition, not at their own words - which can read like a post-political Ideal Type-but at their own actions, thoughts and deeds. From his engagement with such groups, alongside a wider awareness of the literature, North concludes: 'of course this small-scale, convivial, localist vision of Transition initiatives is an inherently political vision' (2011: 1589, original emphasis). Small-scale, seemingly insignificant activity can be 'part of a broader and longer term project that aims to recalibrate inequitable and environmentally ruinous systems' (Hobson et al., 2016a: 5). This article assesses this tension in the literature more closely. How can we critically and fairly account for the politics of community, when it responds to environmental challenges?

\section{Community in post-politics and Transition}

The focus of this paper is in addressing the post-politics of Transition, but such an analysis cannot ignore their understanding and living of community. 'Community' is integral to both Transition and post-political theory. Those diagnosing Transition as post-political regularly invoke geographical theorist Swyngedouw, and his writings on the (post-)political (Dilley, 2017; Kenis and Mathijs, 2014a; Neal, 2013). In turn, Swyngedouw $(2007,2009,2010,2011)$ bases much of his analysis on the philosophy of Jacques Rancière, a key post-political theorist. In tracing the roots of this argument to source, Rancière's key work Dis-agreement (1999) outlines the themes of the political, philosophy and political philosophy. Yet this book is as much laced with discussion of community as it is with 'the political'. For Rancière, politics begins with community. The condition of becoming together with others, being in communion with others, and sharing a common space - all of which Rancière regularly gives the shorthand 'community'- he sees as foundational for politics (1999: 12). Community is the condition of the possibility of being political and acting politically (Rancière, 1999: 5). More precisely, politics is what emerges from different competing visions as to what it means to be in common, who or what is common to 'us', and deciding what the 'common good' means or should come to mean. Post-politics is the idea that certain issues, or 'disagreements', are no longer seen as contested by various actors, with unevenly distributed power. Rather, problems are to be managed, or made more efficient, within a framework of things everybody can agree are good for us all. Necessarily, this presumption of commonality elides the commonality that is provisional, negotiated and in the process of becoming: who are we? what do we want? how can we get it? 
Confusingly, the term 'community' is concurrently identified as post-political because it is a 'Good Thing': an essentialised collective, smoothing over dissent or difference with a wellmeaning, hollowed-out sense of 'pseudo-action', or 'pseudo-belonging', while achieving nothing practical or systematic. Community is one of 'the ways in which the state has reconfigured pro-environmentalism' to its own ends (Barr and Pollard, 2016: 5). More coercively, community is seen as a form of biopower corralling morally responsibly citizens into a natural social order (Dean, 2010; de Wilde, 2015; Hauxwell-Baldwin, 2013; Rose, 2000, 1999). Gilbert argues that a (mistaken) conservative idea — and ideal — of community as either 'a simple aggregation of individuals, or a homogenous and monolithic community' (2014: x) underlies the post-political condition. This idea of community is symptomatic of the "postpolitical trap'- 'intuitively convincing, yet ultimately confining' (Beveridge and Koch, 2017a: 1). The argument is that collective consensus is artificially achieved, by what Rancière calls police order. Police here refers to assumed social norms of behaviour and thought, which is exactly how community has also been seen: a 'prison' or social technology that produces conformity (Bell and Newby, 1971: 36). Community then-in post-political theory-is both the condition of the possibility for being properly political and simultaneously an indicator of post-politics. It all depends on what the community invoked means or does. In order to question just how post-political Transition is then, this article must directly address their mobilisation and practice of community.

Neal (2013) is exemplar here, finding Transition post-political-fitting 'consensus driven political modalities' - primarily due to their mobilisation of 'a specifically rural set of sociospatial imaginaries' (2013: 61), including community. There is indeed a long and strong tradition of community from Tönnies onwards redolent of rurality: settled and static. But this traditional perception of community is not the full story. Not only is it very difficult to fit this simplistic view with many of the recent theoretical writings on community (Claviez, 2016; Esposito, 2010; Nancy, 2016). Transition's community in practice is also uneven. As we shall see, Transition is heavily reliant on mobilising 'community' as an idea and practice, and at times their community is simple, settled and static - rural even. Yet, community is much more capacious than this, and the evidence presented here shows that despite aspects of Transition and their 'community' fitting critical diagnosis, other characteristics are quite distinct.

This article then contributes to the self-critical turn within literature on the post-political, arguing that 'pessimistic and politically disempowering post-political perspectives oversimplify and overestimate the extent' of neoliberalism's dominance (North et al., 2017: 3). Interestingly, North et al. then specifically mention the Transition movement as one of the ways activists 'are building alternatives to neoliberal "business as usual" (North et al., 2017: 3). While building on Swyngedouw and the others mentioned above, recent discussion of the post-political is more nuanced and precise about (post-)political process, what they are claimed to do, or are actually doing (Beveridge and Koch, 2017a, 2017b; Blühdorn, 2015; Derickson, 2017; Dikeç, 2017; Kenis, 2016; Larner, 2015; Swyngedouw, 2017).

\section{Methods}

This article brings together evidence from two large studies of Transition initiatives. First, an ESRC-funded study (Award Number: RES-066-27-0002) looked at the experience and use of 'community' in three separate Transition initiatives and the national hub designed to promote, foster and encourage others (Aiken, 2014). Transition were chosen as the keystone case study due to their emergence as the most prominent and typical representative of the ways in which community responds to environmental challenges 
(North and Longhurst, 2013). These three, a city-centre, suburban and university initiative in one city were chosen to reflect the emerging urban expressions of Transition, as a counterpoint to the more prevalent rural or small town examples, both in practice and the literature at the time (see Table 1 for an overview). They were selected from an initial scoping study of 137 such initiatives that could be found from an internet, literature and snowball sampling investigation over a seven week period. The second study (currently ongoing) investigates a newer Transition initiative (formalised in 2015) in continental Europe, gathering data over the period volunteers coalesced and professionalised (2014-2016). The choice of these cases was designed to further and deepen understanding the dynamics of community-led environmental activity, broaden the sample, and to grasp more specifically the particularities of each initiative. Without systematically comparing, there are many similarities here: the adoption of 'Transition' branding, ideas and ways of thinking; experience of community-based environmentalism in a small European country; the innovative adoption, suspicion of, and playing with a model developed and promoted from semi-rural England. Yet there are also countless differences. Importantly, the cases here are not comparative - either between or within studies - to be so would have called for a different research design from the outset. These four groups are anonymised here, but it is important to draw attention to the fact that, while all are authentically and officially Transition, they comprise variegated ways of being and doing Transition. While these examples are not representative of the entire Transition movement, neither are they outliers. Each, in their own way, can be seen as a 'typical' initiative, chiming with previous research outlining who comprises each initiative, and the specific activities they carry out.

The first project focused on how community was used, adopted, produced and performed in the pursuit of low carbon futures. The second took as its focus a comprehension of the various expressions of community within one country's burgeoning Transition movement. A key research question for this second project, building on the first, was an investigation into what community means, or comes to mean, when used without the semantic associations the English word community brings with it.

These two projects produced a substantial dataset, especially given the experiential, ethnographic, rich and qualitative data gathered. 'Thick' descriptions (Geertz, 2006) and evidence taken from 'ethnographic techniques' (Hammersley and Atkinson, 2007) provide background detail and insights into the issues explored here, though interviews are the main evidence presented. These, between an hour and three hours long were chosen through snowball sampling, and also seeking out prominent figures and voices of the specific initiatives - either the local Transition 'core group' or the specific initiative begun as an expression of Transition - or the national Transition hub. Also interviewed were prominent (Totnes-based) figures of the wider Transition movement. Although anonymised here, many of these figures would be well known in their contexts, whereas others can be seen as 'on the fringes of things' (volunteer). This data then speaks of Transition from top to bottom, inside out. In total, 121 interviews for these projects were transcribed, then-separately for each project — coded and analysed using grounded theory techniques.

Crucial for the 'feel' of these groups and the Transition movement at large were the wider ethnographic techniques. This involved a form of being-with the groups and movements in various mundane activities: from setting out chairs in a town hall before a film screening to knocking on doors for a neighbourhood insulation scheme; from moderating a reading group meeting to volunteering in a community garden. These ethnographic methods have important consequences for the findings. Place-based and ethnographically rich accounts of Transition are important to supplement studies that position them as a grassroots niche, 


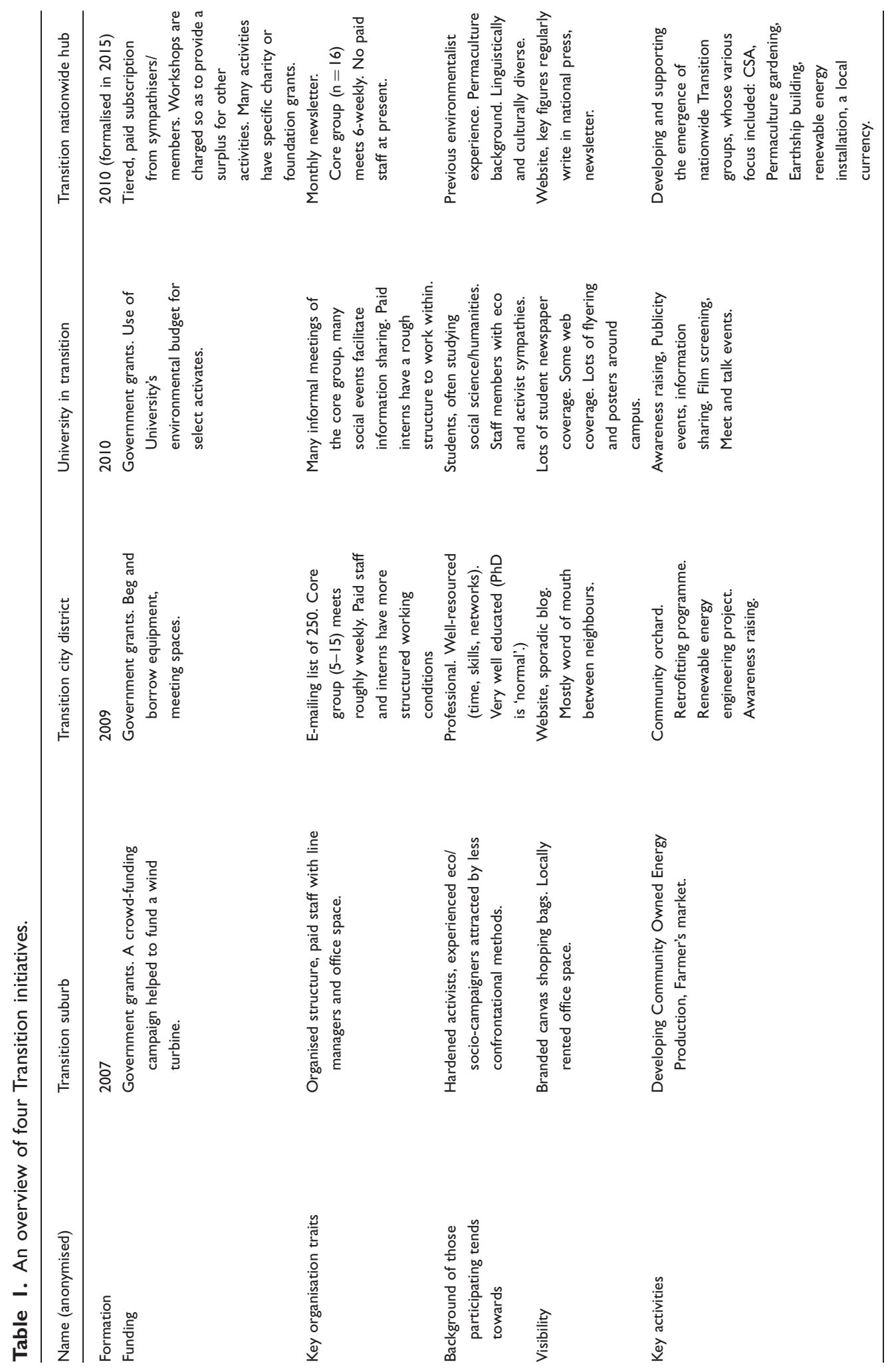


such as Seyfang and Haxeltine (2012), where 'success' is defined by 'scaling-up', or those diagnosing Transition as post-political because they do not 'really change anything'. This, Russi claims, reduce Transition to 'a set of strategies for the implementation of normatively-fixed goals' (Russi, 2015: 61), such as scaling-up, replication, or aiding the improved environmental performance of supply-chains. The intensive rather than extensive experiences of Transition relied on for this paper get away from categorisating Transition into pre-given political/post-political categories. Both small-scale, intensive and broader, more extensive approaches to Transition are clearly describing the same thing, the same social arrangements and movements. Yet, different methodologies can reach different conclusions. Barnes argues that scholars of Transition-at-large often 'characterise the movement's politics as a uniform subject of inquiry' drawing 'reasonable and credible' conclusions (Barnes, 2016: 25), such as that Transition are post-political. But, by refocusing the analytic lens on the local community scale, and by probing the opportunities and strategies for initiatives to spur policy change, subtleties begin to emerge. The extent of political action and the politics of the wider movement are afforded a deeper and more nuanced appreciation.

Depending on one's positionality and methodology then, Transition - and particularly their understanding of community - is revealed differently. Russi parses two Transitions into the earlier Transition Handbook, 12-step approach: 'analytically simplified as a set of strategies to address the problem of peak oil, and - from that initial definition-it can then be set in relation to other terms of measurement or comparison.' (Russi, 2015: 64). Conversely, the more recent Transition Companion, pattern language/ingredient approach: 'endeavor[s] to express the life of Transition's moving on its own terms, with all the orientation dilemmas that can only be sensed from within (but not from without...)' (Russi, 2015: 77). Particularly important to this less strategic, replicable perspective on the movement is their living out of community: a 'willfully indeterminate notion, subject to constant specification as new occasions for common doings arise' (Russi, 2015: 76). This paper's more phenomenological account of Transition chimes with the latter of Russi's categories. Russi's parsing also hints at researcher positionality and methodology as reasons why some researchers reach for the post-political category to understand Transition, while others are less than satisfied with that allocation.

After reflecting on these experiences, this article also suggests that ethnographic engagement can have greater purchase on addressing the political potential of the Transition movement. It is through engaging with communities procedurally that they can move beyond a 'post-political trap': settling, foreclosing possibilities, and shutting down alternatives (Beveridge and Koch, 2017a, 2017b; Larner, 2015). Research on the ground can grasp community as a performative phenomenon, community as a movement. Formally asking 'Is Transition's community post-political?' ironically reifies community, inherently assuming it is static, beyond contestation, assumed not questioned, stable not continually re-framed and posited. Approaching community as a 'thing' or object, not as an event, movement or process has profound implications for the 'community' one finds. Community as a movement aligns with how Rancière (1999, 2009) describes the foundation of the political: capaciously burgeoning with debate, difference, openness to possibilities and futures. This article takes it as axiomatic that several communities can be found lurking behind only one word 'community'.

While this is a considerable fountainhead of experience and data, it remains only one set of viewpoints of Transition, of which there are multiple ways to approach and experience this international, multi-lingual movement. From this longstanding, albeit partial and limited research, three generative themes can be identified. These are outlined next, 
before returning to the article's task at hand: how can we accurately and fairly account for the politics of community within Transition initiatives?

\section{Findings}

\section{Generative theme I: Ecological metaphors}

One commonality in the wide sweep of activities and individuals involved within Transition is an environmental focus. This is clear enough in the goals of the movement, but it also flavours and effects the meanings and self-understandings of Transition. Transition talk about taking a radical approach, but they mean it literally (radical, from the Latin radix, root) - questioning assumptions down to the roots. Transition takes roots and other ecological concepts and apply them to the social and beyond. Fittingly, Transition are a permaculture movement, or a rebranded permaculture way of thinking and acting. Permaculture basically concerns designing (gardens, buildings, the social) in accordance with natural principles and models (Holmgren, 2002). 'Natural' is a hugely complicated and problematic notion, but the invoked idea of nature is an important common feature regularly found in Transition (Henfrey and Penha-Lopes, 2015; Taylor Aiken, 2017).

Transition's original 12 steps were loosely based on permaculture's 12 design principles (Holmgren, 2002) and built on Transition's permaculture heritage, innovatively applying ideas of demise and horizontally operating as a rhizome to environmentalism and social movements. Some steps are literally radical, in that they question sedimented ways of acting and thinking right down to the roots. Environmental groups should be prepared to die, be 'composted' in the belief that something greater, better will 'naturally' emerge. Transition are very adept - not unproblematically — as using natural metaphors and invoking nature to undergird their worldview and ways of operating. For Swyngedouw (2009), this adds fuel to the fire of his claims that environmentalism, and the concept of sustainability, is the perfect arenas where post-politics can be found. Swyngedouw claims this is as the movements are 'predicated upon a radically conservative and reactionary view of a singular-and ontologically stable and harmonious-Nature' (Swyngedouw, 2007: 23). These claims are not unjustified. However a closer look at Transition's view and use of nature-permaculture-infused, horozontalist conceptions of nature, invoking cyclical 'resilience thinking' (Taylor Aiken, 2017; Walker and Salt, 2006) - shows they hardly match Swyngedouw's critique. Far from 'stable and harmonious', Transition also use natural metaphors such as 'composting', 'designed demise', 'managed retreat'.

Crucially too, Transition's community was 'natural', often in reference to natural limits to population, consumption, or size of community. 'When the shit hits the fan, all of us, without exception, will end up in community. Whether we like it or not.' (core member). Community was natural, in that it was a non-ideological way to look at the world: 'this [Transition] is all the opposite to the wider forces out there. Community is being eroded by "Modern Capitalist Society"' (volunteer). Community was an 'intrinsic, deeper shift - it gets away from things like the rebound effect of not flying' (key individual); 'acting as a community is the only way it's gonna work' (volunteer). Many ecological metaphors applied to themselves; groups would 'emerge naturally where they are needed', they would 'fit their environment', 'flourish', 'rejuvenate' or 'evolve'. They were wary of ideas 'transplanted from elsewhere' rather they had to 'dig where they stand'. Groups would gather and 'cross-fertilise', using 'ecological corridors'. Their own involvement was often expressed using natural metaphors too: they had found a 'clearing in their circle of life', or their community as an 'ecological niche'. 
These ecological metaphors have been key to critiquing Transition. An apocalyptic narrative, an event looming in the near-future, used as a mobilising force to corral and collect subjectivities, is a key feature of reactionary discourse in environmental movements (Hoggett, 2011; McKibben, 2006; Skrimshire, 2010; Swyngedouw, 2010). Transition can be seen to use the rhetoric of Peak Oil in a similar way: a near-future 'shock', or looming catastrophe that will ruin the unprepared, or 'save' the ready-those reskilled to survive without oil. Also, some see the function of community as a 'natural' unit of human togetherness, defined by a Dunbar Number, as retaining echoes of environmental determinism. This, alongside community's consensual aspects is precisely the vision of community post-political critiques of Transition focus on.

However, ecological metaphors - creative manipulations of what is considered 'natural'are not destined to be reactionary or post-political. Transition began encouraging new initiatives to 'design their own demise from the outset'. This allowed a 'composting', as a volunteer put it, of social energies, groupings and collectives when they no longer fulfilled their function or use. This is a much more anarchic vision of community, a continual 'breakdown and start again' way of approaching relationships; always on the move, never settled or static (Scott-Cato and Hillier, 2010). Community here is a collective movement and moment: always temporary, tentative and provisional - and all the more important for that. 'Composting' highlights that ecological metaphors per se need not inevitably be postpolitical. It is also a view of 'nature' that refuses to conform to Swyngedouw's blanket view of environmentalist takes on 'nature'. Nature, much like community, is a far more capacious term - in meaning and use - than it is often given credit for.

\section{Generative theme 2: Transition is activity-focused}

Transition volunteers have a clear preference for getting involved. Community gardening or permaculture courses are projects that allowed participants to 'get their hands dirty' (volunteer), work tangibly and practically. A volunteer said: 'the key thing I like about Transition is that it is practical. They are energy-full, you know. It's all about the dynamism.' Those involved in Transition are 'really pragmatic people', added one funder. Other key actors said: 'we want to keep things as practical as possible - not too fluffy'; 'we don't just want to do something idealistic, we are working for something that is useful for us'; 'it's a hearts and minds thing'; 'community reduces the complexity, it shortens the feedback loops'. One volunteer felt Transition to be all about collective practical activity: 'community empowers us more...there's nothing worse than feeling all alone with a problem when working on something'.

One volunteer outlined the importance of activity for Transition's aim of building community: 'it's the small-scale interaction that builds community. Those who volunteer in the community garden end up bonding really well with the folk that come in on their days.' In many interviews a circular argument was made whereby community implied activity within Transition, and Transition's activities led to community. Yet, the association and flowing from each concept to the other-community and activityemphasises how closely they are (assumed to be) related here.

That Transition are an activity-focused, involvement-motivated and engagementorientated movement is one of their most widely identified characteristics. Transition themselves extol the virtues of acting-The Power of Just Doing Stuff (Hopkins, 2013) - and academics recognise that this action implicitly includes acting differently to established or sedimented ways of operating: 'the act and intervention of 'just doing stuff'-and doing it differently from current practices, often in small scale and subtle 
ways - is part of a broader and longer term political project that aims to recalibrate inequitable and environmentally ruinous systems' (Hobson et al., 2016b: 1397).

However, this activity-focus is also criticised as it is pragmatic, engaged in compromise, involves the dilution of ideological purity, and often results in apolitical stances tinkering around the edges of problems, rather than directly confronting ultimate, prime or metaphysically central concepts or causal factors. Common to Transition's practical activity though, is its imbrication with community. Both that the action comes in a collective form - 'we do things together'- but also that the process of being and becoming together comes through practical action. Transition's community is achieved through acting together. Community is both the means and product of their activities.

\section{Generative theme 3: Heterogeneity}

Transition is heterogeneous. Of course, any and all social arrangements are not as monolithic as they seem on the surface, and it usually does not require much experience of a social category to realise that subdivisions and ever-smaller distinctions can always be made. However, Transition's variety goes beyond this. Transition are action-orientated but what this action is changes. Thus the research here looked at a wide panoply of activities. They included the typical, or stereotypical, Transition activities: community gardening, farmer's markets, film screenings, eco-festivals, permaculture courses, insulation programs, (eco-) entrepreneurial workshops, art exhibitions, jam making, film screenings, guerilla gardening, collecting behavior change pledge signatures, yoga courses, reading groups, local currency schemes, and much more.

There were other projects these groups engaged with that went beyond the Transition staple, or stereotype, too. These included: building an Earthship, developing renewable energy projects, retrofitting buildings, founding as ESCO (Energy Service Company), lobbing local companies to change food suppliers, engaging with businesses to develop on-site renewable energy production, or a Combined Heat and Power system, protesting against the establishment of a new supermarket, supporting fellow members running for local election, and much, much more.

The post-political critique correctly identifies that Transition in practice still tends to be found in well-off locations, comprising well-resourced individuals assiduously disavowing conflict or disagreement, with consensus seen as a great virtue. Their spread from Totnes has been geographically uneven. This emphasises and repeats already existing patterns of privilege, or 'hot spots' (Feola and Him, 2016: 2114) of 'alternative milleus' (Longhurst, 2013) rather than challenge or reconfigure these, as has been claimed for the diversity of the movement (Grossmann and Creamer, 2016). However, this analysis can overlook the wide variety of activities (above, and table) Transition engage in. This range of activities then attracts a wide array of participants. The typical or stereotypical Transition volunteer does not exist, or certainly could not be found from the range of groups studied here. Noting that 'diversity and inclusivity are fundamental to Transition philosophy' (2016: 2), Grossmann and Creamer are exemplar in finding that the diversity that does exist within Transition is not at all representative of the places they claim to represent in the initiatives names - in their case, Transition Tooting is far less diverse than Tooting itself. They put this down to the 'passive' approach of engaging and recruiting new members. Transition themselves talk effusively of the right people emerging locally wherever they are needed; often repeating the 'Open Space' principle - 'whoever comes are the right people' (Taylor Aiken, 2017). While this laid back approach to recruitment echoes research here, one important reason why diversity varies across Transition groups is due to variance in their initiatives. 
Those involved - however 'passively' recruited - often act out a furiously committed energy, passionately focused on a series of urgent and goal-orientated actions. It follows that the more assorted the tasks and activities, the more varied the participants who would get involved with and for these.

A passive approach to recruitment results in a relatively homogenous membership. Yet, only if this is accompanied with a passive approach to activity design and focus. Not every Transition group has this passivity. For instance, a highly charismatic character led 'Transition Suburb'. They talked effusively about using permaculture principles to deliberately and purposively design tasks and activities that would attract different personalities, those with varying motivations or competences, and allow different talents to flourish. Where there was more purposiveness in designing activities, these groups tended to be more heterogenous in participation.

The diversity of the Transition movement can be seen not only in essentialised forms of difference (gender, ethnicity) or quantifiable demographic differentials (salary, level of education). A more practice-orientated approach, for instance, starts with the activities groups undertake, rather than the (presumed) qualities or identities each participant possesses. Addressing the demographic details of Transition can indicate a more homogenous form of participants (and community), reflecting underlying patterns of privilege in wider society. The post-political critique has much purchase and is an important and necessary voice here. Conversely, these groups can welcome in participants beyond the 'usual suspects' (volunteer), empower volunteers to 'get involved' (volunteer), and realise what can be achieved through acting in ways they might not have thought of by themselves. Beyond demographics and essentialised understandings of diversity, Transition's practices and inter-subjective activities have much to offer in terms of increasing agency, achieving tasks, getting things done, making a difference-in short, being political. Each of these generative themes have community at root. Each also can take effect through different forms of community.

\section{An applied post-political analysis of transition's community}

Neal's judgment finds Transition post-political due to 'Transition culture's tendency to rely on consensual discourses and values' (2013: 65), primarily community. But is community really a consensual value or discourse? Clearly it can be and has been at times throughout its long and varied trajectory. Community's heritage also includes other contradictory threads though, its polysemic, polyvalent use: community means different things, at different times, to different people. Young (1990) used this to outline difference as being the fundamental basis for any collective togetherness, or community. Opposed to Neal's community assumptions, theorists like Nancy sees community as plural (2000) and an antagonistic mêlée (1991), a fractious (be)coming together characterised by difference, far from a static homogenous arrangement of consensus seekers. Disagreement is not antithetical to community, something to overcome, or elide in order to get to a genuine or harmonious community. Rather, living with difference and disagreement is a crucial part of what it is to belong to a successful community. Many personal experiences of intentional community often begin with the recognition that while they previously assumed a community was positive and affirming from the outside, something lacking in their life perhaps, once 'inside' they had seen the hard work community takes, not least due to the fact that other people, however similar they may appear to be to us, are fundamentally different (Jones, 2007). They are called others for a reason. Indeed it is a common descriptive narrative arc, often told, that disagreements become so challenging and impossible to ignore that intentional communities can fracture, fatally (Evans, 2015). 
Tuckman (1965) famously outlined how groups and communities come together to achieve both cohesion and capacity to act in four sequences. 'Forming, storming, norming, performing' are ubiquitous and oversimplified, but they recognise that disagreement and conflict (storming) are necessary before a community can reach a stage of increased capacity to act (performing). Turkman's typology indicates that community can at times take on post-political characteristics (norming), but the very same community at other times appears properly political (storming, performing). Concluding that community is only, or mostly, about norming, ignores the storming and performing aspects that make up the experience of belonging to a collective. This is just as important a part of community as becoming more alike those we surround ourselves with and belong to.

Neal concludes: 'Transition culture is profoundly entangled with ... a post-political orientation...evident in Transition culture's reliance on the ruralist conception of community:' (2013: 67). But, what community means here is all-important. One community can be reactionary, exclusive, exclusionary and consensus seeking: or, if we must, post-political. Another could be progressive, vanguard and radicalised, political even. Whether Transition are post-political or not is a judgment which rests (silently and implicitly) on whether one assumes community to be inherently, essentially, post-political. Such a presupposition is not only a normative claim, it is also one often made unconsciously.

Transition take permaculture's systems thinking, inherent interrelatedness alongside selfcontained cycling, to avoid any 'artificial separating' of a Transition group from their surrounding social ecology. Thus, they seek to work with established actors such as the local council, and always seek collaborative, mutually beneficial outcomes in the first instance. Hobson et al. (2016b: 1396) add the caveat that these 'win win' assumptions belie the contingencies, diversities and limitations in these examples (Middlemiss, 2011b). Transition eschew - indeed, assiduously avoid - common descriptors of environmentalists and environmentalism: most prominently the term activism or activist. Transition's values and principles that can be seen as both friendly to incumbent or sedimented actors while also radically challenging certain mainstream assumptions, such as growth and oil dependency. This community-based consensus-seeking is at the heart of the post-political diagnosis.

And yet, Transition in the round can fit both 'the political' and post-political checklists. What could be most challenging to police logic than imagining, and then getting stuck in to proleptically inaugurate, a world without oil? For example, Rice argues 'recovering a truly democratic debate will require a move away from [post-political] win-win arguments and toward naming and justifying alternative urban futures, whether capitalist or otherwise' (Rice, 2016: 126). However, there is no reason per se why Transition cannot both utilise their win-win social technologies and also name and justify-indeed, go beyond this to imagine and build - a future world without oil, their resilient relocalised community. This is not to unerringly argue for one side of the political/post-political divide. Those drawing attention to Transition's consensus-seeking, well-resourced demographic, not only have a point, they are an important and necessary critique.

Discussing community initiatives in 'debates about post-politics', Larner argues 'thatironically - the risk is a depoliticized political imaginary, in which choosing one trajectory over another and exploring their articulation with specific programmes and alternatives is not possible.' (Larner, 2015: 204). Something similar exists here, whereby the post-political critique can become totalising, and removes from community its performative functions, or the potential for increasing capacity for activism: agency. The nuance in Kenis and Mathijs' title-(De)politicising the local (2014a) - shows not all post-political critique has this totalising tendency. But, claiming Transition as inherently post-political is a mistake when it rests, as at times it does, on the assumption that any and all forms of community are post- 
political. Community can be political. Indeed for Rancière, claims to the common good and community are the condition of the possibility of being political.

The point of this paper is then not to place, or reposition, Transition somewhere along the properly political/post-political spectrum. Rather it is to abandon the spectrum itself as a less than helpful way to understand Transition and similar initiatives and the potential latent within them to achieve lasting and progressive change within the environmental movement. At root this is a claim that community language and mobilisations are not in themselves a barrier to 'properly political' action. But what community is, does and can be is far more varied than a simple, settled and static assumption. Indeed the notion of 'properly political' can itself be a greater stumbling block to political action than the groups and people to which it is applied.

\section{Conclusions}

This paper has sought to deeply investigate the varieties of community on offer within Transition movements. It does so as, theoretically, community is identified as a key symptom leading to post-political diagnosis. Though Rancière also identifies community as both the condition of the possibility of being political. Everything depends it would seem on how one understands community. The empirical evidence from these case studies indicates likewise. One can very easily find evidence of settled, static and reified community imagined and lived within Transition. Also in their use of what is considered 'natural', the stereotypical activities engaged with, such as community gardening, or the relatively homogenous make up of these groups. And yet, within each of these there also remains evidence indicating the opposite: natural metaphors justifying anarchic (libertarian communist) political viewpoints, activities directly challenging 'big 6' energy companies in the UK or the hold of supermarkets on food supply chains. The article evaluated three generative themes emerging from two heavyduty research projects on Transition. Each of these generative themes provides evidence that can be used to confirm a post-political diagnosis - that Transition's practical action is 'pseudoactivity'; that their diversity is overstated, more in words than deeds; that Transition's ecological metaphors are redolent of environmental determinism, even reactionary. Fundamentally, that Transition's community is consensus seeking and elides more profound antagonisms and differences. The article instead seeks to show that while the post-political critique is not misplaced, a post-political diagnosis can conceal as much as it reveals.

The three generative themes emerging from this research are a case in point. In each case the characteristic of Transition can viewed as either political or post-political. Their practical focus could be seen as pseudo-activity: feel good, affirming actions that fundamentally change nothing. Alternatively, they could lead to getting stuck-in, changing material circumstances and surrounding social and power structures. Their variety of tasks and foci could be seen as piecemeal tinkering around the edges of societies fundamental challenges. Or they could be the means to attract a wider array of participants, to move from essentialised identify definers, to being defied by what they do. The use of environmental metaphors can be seen as further use and abuse of the problematic notion that any social arrangement is 'natural'. Or it could be drawing on an alternative logic to the prevailing assumptions that up-scaling and growing are necessary: that designed demise or composting of social arrangements have as much productive potential as strategically growing. Community lies at the heart of each of these judgments. In each case, the particular social arrangement imagined as the means and end of Transition's activities, social make-up and naturalness, can lean more towards appearing reified, settled and static, or flexiform, variegated and on the move. 
At the heart of this paper is an ontological claim. For Rancière, and those following him, Swyngedouw especially, the empirical finding of consensus-seeking is an indicator of postpolitics. This post-political diagnosis then results in a host of related terms then being applied: they engage in a form of 'pseudo-activity', feel-good action of little or no consequence, at best ignorant, at worse a stumbling block to their ultimate aim. Just as in post-political theory community can be seen as both post-political and political, in Transition likewise, community can provide ample fuel for the fire of those seeking to label Transition postpolitical. Yet, this is not the whole story, and with a different theoretical lens, one could identify Transition's community as the precondition for the possibility of being political in environmentalism.

\section{Acknowledgements}

This paper was first presented at the Climate Change Study Group of the European Society for European Sociology in Aberdeen, in 2015. I thank Liz Dinnie and that group for that invitation and for the opportunity to clarify and improve this argument. I particularly want to thank Annabel Pinker for the thought provoking questions, and Jan Doerr, Bû̀rû̀nice Jung-Preller, Christian Schulz and Ben Schmid, for comments on earlier drafts. The peer-review process also improved the article. The remaining faults are my own.

\section{Declaration of conflicting interests}

The author(s) declared no potential conflicts of interest with respect to the research, authorship, and/or publication of this article.

\section{Funding}

The author(s) disclosed receipt of the following financial support for the research, authorship, and/or publication of this article: The research for this article was partially funded as part of the wider ESRC Climate Change Fellowship 'Urban Transitions: climate change, global cities and the transformation of socio-technical networks' (Award Number: RES-066-27-0002), led by Harriet Bulkeley.

\section{References}

Agyeman J, Schlosberg D, Craven L, et al. (2016) Trends and directions in environmental justice: From inequity to everyday life, community, and just sustainabilities. Annual Review of Environment and Resources 41: 321-340.

Aiken G (2012) Community transitions to low carbon futures in the transition towns network (TTN). Geography Compass 6: 89 -99.

Aiken G (2014) The production, practice and potential of 'community' in Edinburgh's Transition Town Network. PhD Thesis, Durham University, Durham.

Bailey I, Hopkins R and Wilson G (2010) Some things old, some things new: The spatial representations and politics of change of the peak oil relocalisation movement. Geoforum 41: 595-605.

Barnes P (2016) Transition initiatives and confrontational politics: Guidelines, opportunities, and practices. In: Presented at the Western Political Science Association 2016 Annual Meeting, San Diego, California, 24 March 2016.

Barr S and Devine-Wright P (2012) Resilient communities: Sustainabilities in transition. Local Environment 17: 525-532.

Barr S and Pollard J (2016) Geographies of transition: Narrating environmental activism in an age of climate change and Peak Oil. Environment and Planning A 49: 47-64. 
Bell CR and Newby H (1971) Community Studies: An Introduction to the Sociology of the Local Community, Studies in Sociology. London: Allen and Unwin.

Beveridge R and Koch P (2017a) The post-political trap? Reflections on politics, agency and the city. Urban Studies 54: 31-43.

Beveridge R and Koch P (2017b) What is (still) political about the city? Urban Studies 54: 62-66.

Blühdorn I (2015) Post-ecologist governmentality: Post-democracy, post-politics and the politics of unsustainability. In: Wilson $\mathrm{J}$ and Swyngedouw E (eds) The Post-Political and Its Discontents: Spaces of Depoliticisation, Spectres of Radical Politics. Edinburgh: Edinburgh University Press.

Brangwyn B (2010) What is a transition initiative? Transit Network. Available at: https://www. transitionnetwork.org/support/what-transition-initiative (accessed 17 August 2011).

Brown G, Kraftl P and Pickerill J (2012) Holding the future together: Towards a theorisation of the spaces and times of transition. Environment and Planning A 44: 1607-1623.

Bulkeley H and Fuller S (2012) Low carbon communities and social justice. JRF viewpoints Ref. 2741.

Chatterton P (2016) Building transitions to post-capitalist urban commons. Transactions of the Institute of British Geographers 41: 403-415.

Chatterton P and Cutler A (2008) The Rocky road to a real transition: The transition towns movement and what it means for social change. Trapese Collective 42. Available at: http://trapese. clearerchannel.org/resources/rocky-road-a5-web.pdf

Claviez T (ed) (2016) The Common Growl: Toward a Poetics of Precarious Community. 1st ed. New York: Commonalities. Fordham University Press.

Cook IR and Swyngedouw E (2012) Cities, social cohesion and the environment: Towards a future research agenda. Urban Studies 49: 1959-1979.

Creamer E (2015) "Community": The means and ends of sustainability? Exploring the position and influence of community-led initiatives in encouraging more sustainable lifestyles in remote rural Scotland. PhD, University of Edinburgh, Edinburgh.

Cretney RM, Thomas AC and Bond S (2016) Maintaining grassroots activism: Transition Towns in Aotearoa New Zealand: Maintaining grassroots activism. New Zealand Geographic 72: 81-91.

Dean M (2010) Governmentality: Power and Rule in Modern Society, 2nd ed. London; Thousand Oaks, CA: SAGE.

Derickson KD (2017) Taking account of the "part of those that have no part.". Urban Studies 54: 44-48.

de Wilde M (2015) Brave new neighbourhood: Affective citizenship in Dutch territorial governance. $\mathrm{PhD}$ Thesis, Universiteit van Amsterdam, Amsterdam.

Dikeç M (2017) Disruptive politics. Urban Studies 54: 49-54.

Dilley LTM (2017) Avoiding the political in transition: A micro-analysis of the micro-politics of conflict. Journal of Rural Studies 51: 178-188.

Esposito R (2010) Communitas: The Origin and Destiny of Community, Cultural Memory in the Present. Stanford, CA: Stanford University Press.

Evans D (2015) The utopia experiment. London: Picador.

Feola G and Him MR (2016) The diffusion of the Transition Network in four European countries. Environment and Planning A 48: 2112-2115.

Feola G and Nunes R (2014) Success and failure of grassroots innovations for addressing climate change: The case of the Transition Movement. Global Environmental Change 24: 232-250.

Geertz C (2006) The Interpretation of Cultures: Selected Essays, Nachdr. ed. New York: Basic Books.

Gilbert J (2014) Common Ground: Democracy and Collectivity in an Age of Individualism. London: Pluto Press.

Grossmann M and Creamer E (2016) Assessing diversity and inclusivity within the Transition movement: An urban case study. Environmental Politics 26: 161-182.

Hammersley M and Atkinson P (2007) Ethnography: Principles in Practice, 3rd ed. London; New York: Routledge.

Hauxwell-Baldwin R (2013) Tackling climate change through community: The politics and practice of the low carbon communities challenge. $\mathrm{PhD}$, University of East Anglia. 
Henfrey $T$ and Penha-Lopes $G$ (2015) Permaculture and climate change adaptation: Inspiring ecological, social, economic and cultural responses for resilience and transformation. Hampshire: Permanent Publications.

Hobson K, Hamilton J and Mayne R (2016a) Monitoring and evaluation in UK low-carbon community groups: Benefits, barriers and the politics of the local. Local Environment 21: 124-136.

Hobson K, Mayne R and Hamilton J (2016b) Monitoring and evaluating eco-localisation: Lessons from UK low carbon community groups. Environment and Planning A 48: 1393-1410.

Hoggett P (2011) Climate change and the apocalyptic imagination. Journal for the Psychoanalysis of Culture and Society 16: 261-275.

Holmgren D (2002) Permaculture: Principles \& Pathways Beyond Sustainability. Holmgren Design Services, Hepburn, Vic, Australia.

Hopkins R (2008a) The Transition Handbook: From Oil Dependency to Local Resilience. Totnes, Devon: Green Books.

Hopkins R (2008b) The Rocky road to a real transition: A review. Transition Culture. Available at: http://transitionculture.org/2008/05/15/the-rocky-road-to-a-real-transition-by-paul-chattertonand-alice-cutler-a-review/ (accessed 29 May 2015).

Hopkins R (2011) The Transition Companion: Making Your Community More Resilient in Uncertain Times. Totnes: Transition Books.

Hopkins R (2013) The Power of Just Doing Stuff: How Local Action Can Change the World. Cambridge: Green Books.

Jones T (2007) Utopian Dreams: In Search of a Good Life. London: Faber and Faber.

Kenis A (2016) Ecological citizenship and democracy: Communitarian versus agonistic perspectives. Environmental Politics 25: 949-970.

Kenis A and Lievens M (2014) Searching for "the political" in environmental politics. Environmental Politics 23: 531-548.

Kenis A and Lievens M (2015) The Limits of the Green Economy: From Reinventing Capitalism to Repoliticising the Present, Routledge Studies in Environmental Policy. London: Routledge.

Kenis A and Mathijs E (2014a) (De)politicising the local: The case of the Transition Towns movement in Flanders (Belgium). Journal of Rural Studies 34: 172-183.

Kenis A and Mathijs E (2014b) Climate change and post-politics: Repoliticizing the present by imagining the future? Geoforum 52: 148-156.

Larner W (2015) The limits of post-politics: Rethinking radical social enterprise. In: Wilson J and Swyngedouw E (eds) The Post-Political and Its Discontents: Spaces of Depoliticisation, Spectres of Radical Politics. Edinburgh: Edinburgh University Press, pp. 189-207.

Longhurst N (2013) The emergence of an alternative milieu: Conceptualising the nature of alternative places. Environment and Planning A 45: 2100-2119.

McKibben B (2006) How Close to Catastrophe? New York: N. Y. Rev. Books.

Mason K and Whitehead M (2012) Transition urbanism and the contested politics of ethical place making. Antipode 44: 493-516.

Merritt A and Stubbs T (2012) Incentives to promote Green Citizenship in UK transition towns. Development 55: 96-103.

Middlemiss L (2011a) The power of community: How community-based organizations stimulate sustainable lifestyles among participants. Society \& Natural Resources 24: 1157-1173.

Middlemiss L (2011b) The effects of community-based action for sustainability on participants' lifestyles. Local Environment 16: 265-280.

Middlemiss L and Parrish BD (2010) Building capacity for low-carbon communities: The role of grassroots initiatives. Energy Policy 38: 7559-7566.

Moloney S, Horne RE and Fien J (2010) Transitioning to low carbon communities-From behaviour change to systemic change: Lessons from Australia. Energy Policy 38: 7614-7623.

Mouffe C (2005) On the Political, Thinking in Action. London; New York: Routledge.

Nancy J-L (2016) The Disavowed Community, 1st ed. New York, NY: Commonalities. Fordham University Press. 
Nancy J-L (1991) The Inoperative Community, Theory and History of Literature. Minneapolis, MN: University of Minnesota Press.

Nancy J-L (2000) Being Singular Plural, Meridian, Crossing Aesthetics. Stanford, CA: Stanford University Press.

Neal S (2013) Transition culture: Politics, localities and ruralities. Journal of Rural Studies 32: 60-69.

North P (2010) Eco-localisation as a progressive response to peak oil and climate change - A sympathetic critique. Geoforum 41: 585-594.

North P (2011) The politics of climate activism in the UK: A social movement analysis. Environment and Planning $A$ 43: 1581-1598.

North P and Longhurst N (2013) Grassroots localisation? The scalar potential of and limits of the "transition" approach to climate change and resource constraint. Urban Studies 50: $1423-1438$.

North P, Nurse A and Barker T (2017) The neoliberalisation of climate? Progressing climate policy under austerity urbanism. Environment and Planning A 49: 1797-1815.

Rancière J (1999) Disagreement: Politics and Philosophy. Minneapolis: University of Minnesota Press.

Rancière J (2009) Hatred of Democracy, Paperback edition. London: Verso.

Rice JL (2016) “The Everyday Choices We Make Matter": Urban climate politics and the postpolitics of responsibility and action. In: Towards a Cultural Politics of Climate Change: Devices, Desires, and Dissent. Cambridge: Cambridge University Press, pp.110-126.

Rose NS (1999) Powers of Freedom Reframing Political Thought. Cambridge, United Kingdom; New York: Cambridge University Press.

Rose N (2000) Community, citizenship, and the third way. American Behavioral Scientist 43: $1395-1411$.

Russi L (2015) Everything Gardens and Other Stories: Growing Transition Culture. Plymouth: University of Plymouth Press.

Schmitt C (2005) Political Theology: Four Chapters on the Concept of Sovereignty. Chicago: University of Chicago Press.

Schmitt C (2007) The Concept of the Political, Expanded ed. Chicago: University of Chicago Press.

Scott-Cato M and Hillier J (2010) How could we study climate-related social innovation? Applying Deleuzean philosophy to Transition Towns. Environmental Politics 19: 869-887.

Seyfang G and Haxeltine A (2012) Growing grassroots innovations: Exploring the role of communitybased initiatives in governing sustainable energy transitions. Environment and Planning C: Government and Policy 30: 381-400.

Skrimshire S (ed) (2010) Future Ethics: Climate Change and Apocalyptic Imagination. London; New York: Continuum.

Smith A, Hargreaves T, Hielscher S, et al. (2016) Making the most of community energies: Three perspectives on grassroots innovation. Environment and Planning A 48: 407-432.

Staggenborg S and Ogrodnik C (2015) New environmentalism and Transition Pittsburgh. Environmental Politics 24: 723-741.

Swyngedouw E (2007) Impossible "Sustainability" and the postpolitical condition. In: Krueger R and Gibbs D (eds) The Sustainable Development Paradox: Urban Political Economy in the United States and Europe. New York, NY: Guilford Press, pp. 13-40.

Swyngedouw E (2009) The antinomies of the postpolitical city: In search of a democratic politics of environmental production. International Journal of Urban and Regional Research 33: 601-620.

Swyngedouw E (2010) Apocalypse forever? Post-political populism and the spectre of climate change. Theory, Culture \& Society 27: 213-232.

Swyngedouw E (2011) Depoliticized environments: The end of nature, climate change and the postpolitical condition. Royal Institute of Philosophy Supplements 69: 253-274.

Swyngedouw E (2017) Unlocking the mind-trap: Politicising urban theory and practice. Urban Studies 54: 55-61.

Taylor Aiken G (2016) Prosaic state governance of community low carbon transitions. Political Geography 55: 20-29. 
Taylor Aiken G (2017) Permaculture and the social design of nature. Geografiska Annaler Series B Human Geography 99: 172-191.

Taylor Aiken G, Middlemiss L, Sallu S, et al. (2017) Researching climate change and community in neoliberal contexts: An emerging critical approach. Wiley Interdisciplinary Reviews: Climate Change 8: e463. DOI: $10.1002 /$ wcc.463.

Tuckman B (1965) Developmental sequence in small groups. Psychological Bulletin 63: 384-399.

Walker G (2011) The role for "community" in carbon governance. Wiley Interdisciplinary Reviews: Climate Change 2: 777-782.

Walker BH and Salt D (2006) Resilience Thinking: Sustaining Ecosystems and People in a Changing World. Washington, DC: Island Press.

Young IM (1990) Justice and the Politics of Difference. Princeton, NJ: Princeton University Press.

Žižek S (1999) The Ticklish Subject: The Absent Centre of Political Ontology, Reprint. ed. London: Wo es war. Verso. 